\title{
Regional Skill Ecosystems to Assist Young People Making Education Employment Linkages in Transition from School to Work
}

\author{
Paul Dalziel \\ Professor of Economics \\ Agribusiness and Economics Research Unit, Lincoln University \\ NEW ZEALAND \\ (paul.dalziel@lincoln.ac.nz)
}




\section{Abstract}

A feature of regional development in New Zealand over the last two decades has been ongoing skill shortages reported by employers at the same time as unemployment has been relatively high. This paper addresses that issue with findings from a five-year trans-disciplinary research programme on education employment linkages for young people. The author's contribution to that programme focused on employer-led channels at the regional level, investigating how employment opportunities and requirements in a region are communicated to young people as they make education choices. This paper pays particular attention to the role of careers offices in post-school education institution, drawing on the skill eco-system metaphor introduced initially by David Finegold (1999) and developed more recently by the NSW Board of Vocational Education and Training in Australia in collaboration with a research team led by John Buchanan at the University of Sydney.

\section{Acknowledgements}

Earlier versions of this paper were presented at three conferences: the North American Regional Science Council conference, Ottawa, 7-10 November 2012; the Australia and New Zealand Regional Science Association International conference, Wollongong, 4-7 December 2012; and the Regional Studies Association conference, Izmir, 15-18 June 2014. I am grateful for feedback at those conferences and also to my research colleagues, Jane Higgins, Hazel Phillips and Karen Vaughan for their collaboration over five years. I thank two anonymous referees for this journal for their insightful comments. I am also grateful to Chris Bridgman, Joanna Consedine, Dave Petrie and Robyn Cummins at the University of Canterbury Careers, Internships and Employment centre, who agreed to act as research partners for the study. I thank Lynn McClelland (Director of Communications and External Relations at the University of Canterbury) who gave permission for the project. I thank Simon Worthington (Workforce Strategy Manager for the Canterbury Development Corporation, also working on secondment for the Canterbury Earthquake Recovery Authority) for his participation in and contributions to this research. Finally, I thank Etienne Nel for his invitation to contribute to this special issue of Local Economy. 


\section{Regional Skill Ecosystems to Assist Young People Making Education Employment Linkages in Transition from School to Work}

\section{Introduction}

One of the stylised facts reported by regional studies is that there is a wide variance in the distribution of "skills" across a country's geography. A recent study on cities, skills and regional change by Edward Glaeser et al. (2014), for example, presented United States post-war data showing that "the older areas that were best placed to reinvent themselves had a heavy concentration of skills and disproportionate number of small firms, which may be a proxy for the level of entrepreneurial human capital" (p. 33). Using European data, Crespo Cuaresma et al. (2014) reported in the same journal that regions with a large share of workers with a higher education tend to grow faster. This stylised fact is leading to considerable research on how skills are developed at the national and subnational levels (see, for example, Buchanan et al, forthcoming).

Against that wider background, concerns have been expressed about the experience of New Zealand young people in regional labour markets. An OECD report on jobs for youth, for example, found that "transitions from school to work are relatively smooth in New Zealand" but also identified three weaknesses that needed to be addressed (OECD, 2008, pp. 9-10): (1) there is a hard-core of youth who are at high risk of poor labour market outcomes and social exclusion; (2) not enough young people pursue vocational studies despite excellent labour market prospects offered by many trade professions and at the same time, some tertiary institutions do not provide youth with the skills required in the labour market; and (3) current labour market policies do not easily reach young people who have disengaged from school at an early age and are not entitled to welfare support. In May 2011, the Prime Minister's Chief Science Advisor (Sir Peter Gluckman) released a substantial report on adolescence transitions. It recognised the difficulties faced by the current generation of youth and quoted OECD data to "suggest that young New Zealanders are at greater risk than those of virtually any other nation we would want to compare ourselves with" (Gluckman, 2011, p. 4). Another report published two months later by the New Zealand Institute put economic problems at the centre of its analysis of youth disadvantage (Boven et al, 2011, pp. 2-3): 
New Zealand 'allocates' a higher share of unemployment to its youth than any other OECD country. Forty-five per cent of New Zealand's total unemployed are youth. Youth aged 20 to 24 years have similar experiences to 20 to 24 year olds in other OECD countries so it is the 15 to 19 year olds here who are different.

Many OECD countries insulate their 15 to 19 year olds from unemployment by keeping them in education or training so they are not in the labour force. New Zealand does not; it has the lowest median age of leaving initial education among OECD countries. Far too many youth are leaving school early and not successfully transitioning to work.

At the same time as a sizeable portion of the youth population is experiencing difficulties in their transition years, New Zealand employers are reporting significant skill shortages. The Department of Labour (absorbed into the Ministry of Business, Innovation and Employment on 1 July 2012), for example, maintains a Long Term Skill Shortage List and an Immediate Skill Shortage List that are used as part of New Zealand's immigration policy. It is not easy to have an occupation included on these lists. The occupation must be highly skilled and the industry needs to demonstrate its commitment to training New Zealanders and to fully utilising the domestic labour market before looking overseas. For the Immediate Skills Shortage List, evidence must be confirmed of shortage in specific geographic regions; for the Long Term List, there must be an ongoing and sustained shortage, both globally and across all geographic regions in New Zealand. Despite these stringent requirements, there are large numbers of occupations on both lists. In September 2012, there were 101 occupations on the immediate list and 128 occupations on the long term list. Further, the lists include occupations for which qualifications are not particularly sophisticated; for example: arborist, assistant herd manager, automotive electrician, baker, chef, general electrician, jockey and uphoslster.

These observations suggest regional skills mismatches. ${ }^{1}$ At the same time that sizeable numbers of young people are struggling to create good education and employment pathways for themselves, employers are reporting occupations with immediate or long term skills shortages. Such patterns are not unique to New Zealand, of course; the $\operatorname{OECD}(2011,2012)$ has emphasised the importance of national skills strategies as key for boosting employment and economic growth, and for promoting social inclusion.

Against that background, the Education Employment Linkages research programme was a trans-disciplinary research programme funded from the New Zealand Public Good Science Fund from 1 July 2007 to 30 September 2012 (www.eel.org.nz). Its aim was to answer the question: How can formal support systems best help young New Zealanders make good education employment linkages to benefit themselves, their communities, and the national economy? This paper presents a partial answer to that question, drawing on a fuller report by Dalziel (2012). It ends with a proposal for a New Zealand system of regional skill ecosystems that makes use of regionally embedded networks that include the careers education offices of secondary and tertiary education organisations as key nodes.

\footnotetext{
${ }^{1}$ In New Zealand, "regions" can be used to describe subnational territories defined at a range of scales depending on context. The most common usage refers to areas governed by one of the country's 17 Regional Councils under the Local Government Act, 2002.
} 
The paper is organised as follows. Section 1 provides an overview and synthesis of three important strands in the economics literature concerned with skills formation: the comparative advantage model of Roy (1951); the human capital model of Mincer (1958), Shultz (1961) and Becker (1962, 1964); and the signalling model of Spence (1973). Section 2 develops that synthesis to incorporate the standard economic model of an enterprise to create a model of a regional skill ecosystem of the type first discussed by Finegold (1999) and developed by Buchanan (2006) and others.

Section 3 considers the importance of networking activities in the contexts of regional development (drawing on Rutten and Boekema, 2012) and of careers education. It begins with careers education in New Zealand secondary schools (drawing on Vaughan and O'Neil, 2010) and then reports on a case study that explored networking activities for careers education in a tertiary education organisation. The study found that networks are important, conceptualising the work of a careers office in such an organisation as offering an integrated set of menus of services provided to employers, students and faculties.

Section 4 explains the proposal for a system of regional skill ecosystems anchored by Careers New Zealand (a government agency providing leadership and expertise across the careers sector) as the system's national spine. The paper ends with a brief conclusion.

\section{A Synthesis Model of Education and Labour Market Skills}

The section brings together three important contributions in the economics literature to modern understandings of skills. One of the earliest contributions came in an article by Roy (1951) offering "some thoughts on the distribution of earnings". The article was "intended to combat the view that the distribution of incomes is an arbitrary one that has developed by the process of historical accident" (idem, p. 135). Instead Roy adopted the theory of comparative advantage to cover the situation "in which individuals' comparative advantages in various activities differ widely" (idem, p. 145). He concluded (idem, p. 146):

It has been shown, granted the truth of the particular assumptions made, that the distribution of earnings depends on certain 'real' factors, i.e. the character of the distributions of various kinds of human skill and the state of technique existing in different occupations. The desires of the individuals in the community for various sorts of goods are naturally of great importance too, but they are only able to exert their influence within the framework determined by skill and technique.

Roy's model continues to inspire further research; see, for example, Heckman and Honoré (1990). It points to a key purpose of the education system, going back at least to Rousseau (1762), which is to help students discover more about their individual interests and abilities. This has led economists to develop sequential models in which students learn in early periods of education about their interests and abilities and this new knowledge then shapes education choices in later periods (see, for example, Altonji, 1993, Weiler, 1994, Keane and Wolpin, 1997 and 2000, Eckstein and Wolpin, 1999, and Arcidiacono, 2004). 
A second major contribution by economists was the development of human capital theory by Mincer (1958), Shultz (1961) and Becker $(1962,1964)$. The theory rests on recognition that a decision to spend time in education has strong similarities to an enterprise's decision to use savings to invest in physical capital. In particular, an individual in education foregoes current consumption in order to acquire 'human capital' that will increase their productivity in employment and so allow future earnings at a premium above the wages earned by uneducated workers. This model has generated a vast literature; Harmon et al. (2003), Sianesi and Van Reenen (2003) and Tobias and Li (2004) provide recent surveys.

A third major contribution highlights the role of educational qualifications in signalling the student's ability to potential employers. This literature began with Spence's (1973) article on job market signalling; see reviews by Weiss (1995) and Riley (2001 pp. 459-463). Spence made the point that this signalling role of completed qualifications can be sustained even if participation in education does not itself add anything to the student's endowed abilities. This is because high ability individuals find it less costly to engage in education for a number of reasons and so potential employers will recognise that an individual who has chosen to obtain a qualification must have high ability to justify that investment. This mechanism is stronger if education does indeed increase a person's human capital (Riley, 2001, p. 460).

Figure 1: A stylised model of skills formation

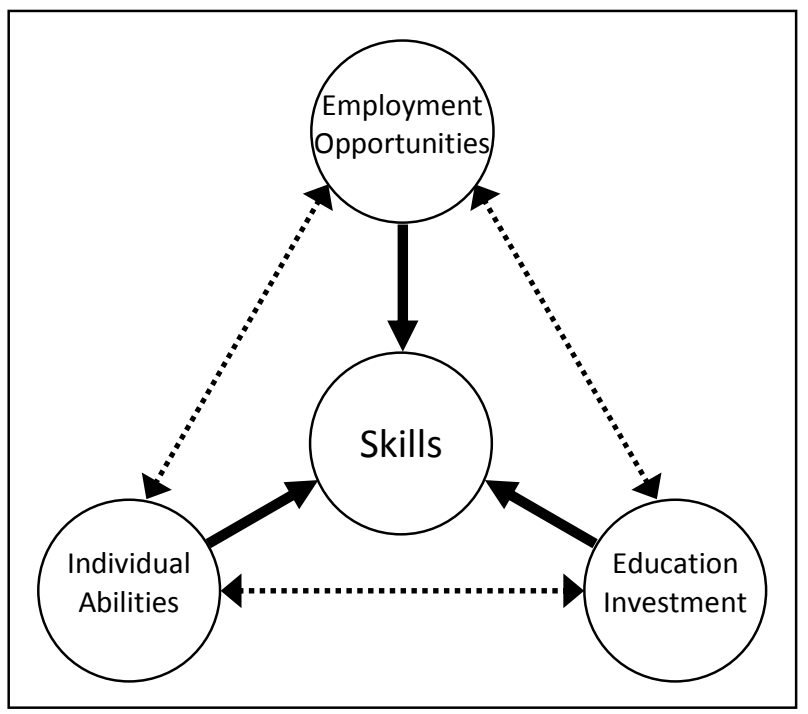

Source: Dalziel (2012, Figure 11, p. 21).

The three models are brought together in Figure 1, first developed in Dalziel (2010 and 2011). It suggests that labour market skills require three elements to be matched: individual abilities; education investment; and employment opportunities. Roy's model supports the first matching arrow, connecting individual abilities and employment opportunities. The human capital model supports the bottom matching arrow, connecting individual abilities and education investment. The signalling model supports the third matching arrow in the figure, connecting education investment and employment opportunities through graduates using qualifications to display their disciplined abilities to potential employers. 
An important feature of the model in Figure 1 is that it captures the importance of human capital in skills formation, but also emphasises the matching of individual abilities with employment opportunities, as well as the signalling role of qualifications that links education investment to employment opportunities. Thus the model recognises that investment in human capital is not sufficient for creating marketable skills. This has been noted, for example, by Quintini (2011, pp. 45-46):

Despite the significant role played by individual skill heterogeneity in explaining qualification mismatch and its repercussions on wages, policy intervention may be warranted to address a number of issues. These include, notably: the mis-investment in education implicit in large numbers of youth leaving school without the skills that employers require; the costs incurred by firms to sort candidates into jobs when qualifications provide bad signals for skills; and the difficulties faced by some specific groups such as job losers and immigrants.

The first two issues identified by Quintini are exactly the two consequences of using an impoverished model of labour market skills that does not include the links with employment opportunities. Quintini (2011, p. 46) continues that "policy interventions designed to reduce mismatches require the co-operation of the many different actors involved in generating jobs, imparting and acquiring skills and bringing jobs and workers together: employers, educators, individual workers, central and local governments, public employment services and the social partners". This idea has led some analysts to argue that a region's skill development system should be considered as an ecosystem (see, for example, Committee for Auckland, 2012, p. 17), as explained in the following section.

\section{A Model of a Regional Skill Ecosystem}

An early use of the 'skill ecosystem' phrase was by Finegold (1999). Finegold researched "the dense concentrations of biomedical and computer hardware and software firms clustered in Northern and Southern California", which had become "self-sustaining high-skill ecosystems" (idem, p. 61). In proposing this label, Finegold was self-consciously moving away from former frameworks based on low-skill versus high-skill equilibria, explaining "both concepts [equilibria and ecosystems] highlight the interdependence of actors in a system, but in the study of ecosystems the focus is on continual evolution" (idem, p. 63).

In 2000, the New South Wales Board of Vocational Education and Training commissioned a multi-disciplinary team of researchers from the Australian Centre for Industrial Relations Research and Training at the University of Sydney and from the Research Centre for Vocational Education and Training at the University of Technology Sydney to undertake a project on linkages (present and future) between work and skills. The aim was to describe policy options for shaping those connections in the future. The project drew on Finegold's 'skill ecosystem' metaphor; Buchanan et al. (2001, p. 11):

Understanding how both 'general trends' and 'diversity' cohere in practice is best achieved by using the notion of 'skill ecosystems' - ie clusters of high, intermediate and low level competencies in a particular region or industry shaped by interlocking networks of firms, markets and institutions. 
Subsequently, two pilot programmes successfully tested the skill ecosystem idea, highlighting the way in which different groups of actors (individuals, educators, employers and policy advisors) must be motivated by mutually reinforcing advantages for a high skill ecosystem to flourish; see Buchanan (2006), Windsor and Alcorso (2008) and Buchanan and Jakubauskas (2010, pp. 44-49).

A model that captures these insights can be developed from the model in Figure 1 in two steps (see Dalziel, 2011a and 2011b, and Miranda et al, 2011, p. 68). The first step considers the situation of employers and their motivation for utilising skilled employees. It is assumed that the motivation is to earn profits, which is achieved by matching market opportunities with investment in capital that is in turn matched by the employment of productive workers who can utilise the capital to take advantage of the market opportunity. This model is shown in Figure 2.

Figure 2: A stylised model of skills utilisation

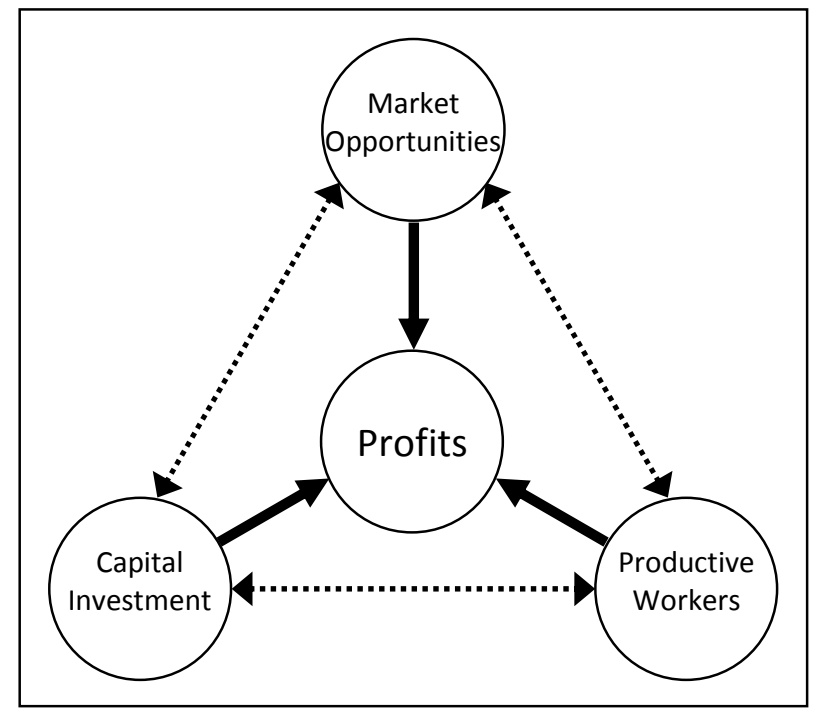

Source: Dalziel (2012, Figure 4, p. 14).

The second step is to combine the two models. At the heart of the employees' model in Figure 1 lies 'skills' defined in the sense of having labour market value. At the heart of the employers' model in Figure 2 lies 'profits' required for the enterprise to be financially sustainable. The two models are connected, however, since it is an employer's profits that give rise to employment opportunities and it is an employee's skills that define productive workers. Hence the two diagrams are elements of a more integrated model, obtained by rotating the diagram of Figure 1 and 'clicking' it into the diagram of Figure 2 to produce the synthesis model of a skill ecosystem in Figure 3.

The model in Figure 3 has a number of attractive features, starting with the binary relationship between skills and profits at its core. The key to high productivity is the ability of enterprises to create profits through using skilled employees receiving a just return on their investment in gaining those skills. Another attractive feature highlights the importance of market 
opportunities and individual abilities (with both concepts broadly defined) as the foundation for profits and skills. This indicates the importance of a sound economic development strategy and of investing in the education of the next generation.

A third attractive feature is that the model in Figure 3 illustrates the coordination problem within a skills ecosystem that is the focus of this paper. Employers make capital investment decisions separately from the education investment decisions of current and potential employees. This separation means employers can be constrained by skill gaps in the labour force while potential workers can waste time and financial resources by investing in education that is out-of-date or produces skills for which there is no employer demand. One of the major purposes of the policy environment within which the skills ecosystem sits is to address this coordination problem. ${ }^{2}$

Figure 3: A model of a skill ecosystem

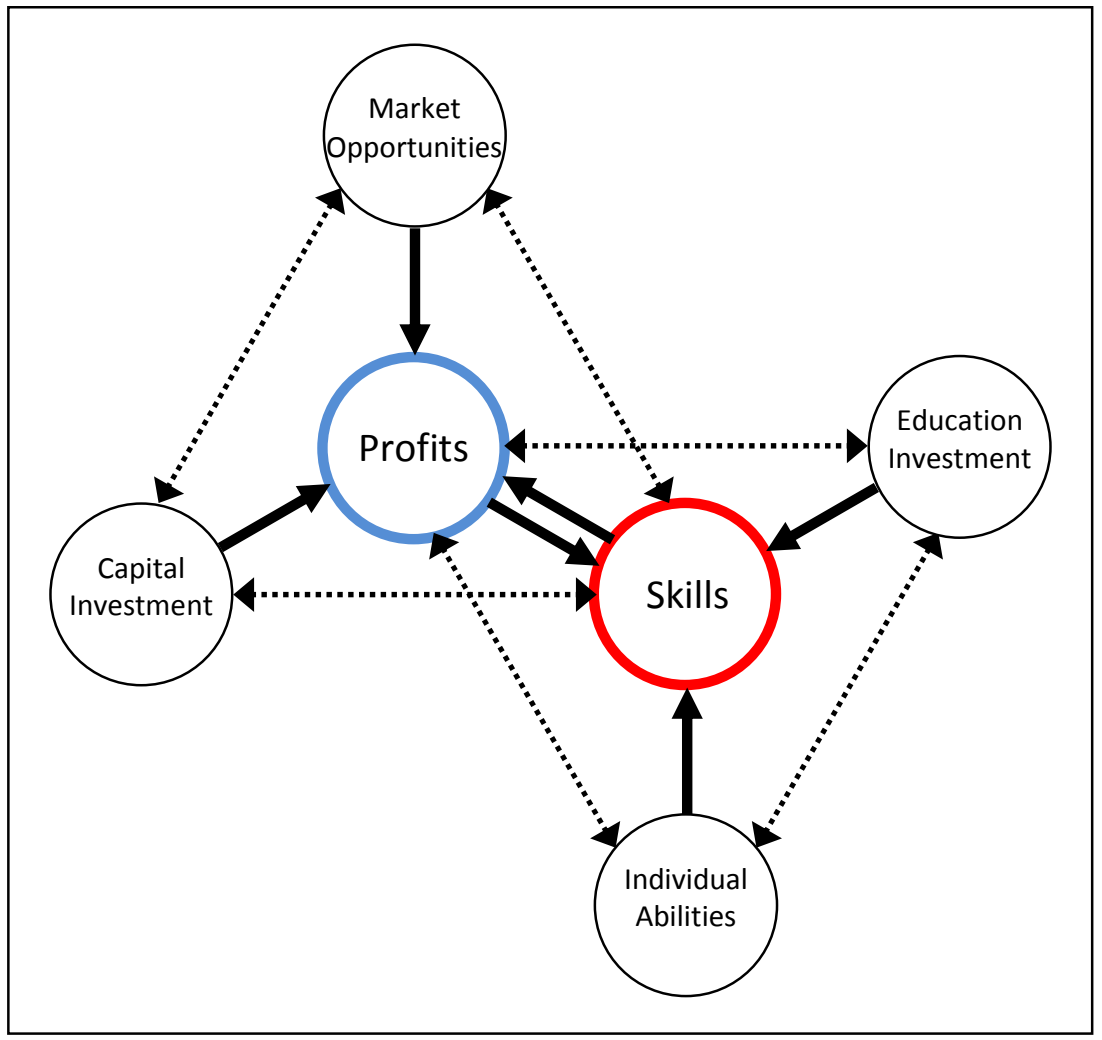

Source: Dalziel (2012, Figure 19, p. 38).

\footnotetext{
${ }^{2}$ A referee perceptively emphasises the wider background of economic, social and technological changes that continuously buffet a region's industries and therefore skill requirements. This suggests the need to think about networking protocols to ensure a skills ecosystem remains adaptable to unknown and fast-moving skill requirements. The referee also suggests correctly that there may be several overlapping skills ecosystems in any particular region, depending on the region's industry structure and educational systems.
} 
The possibility of coordination failure has given rise to a group of professionals engaged in secondary schools and elsewhere to help youth consider their choices. Traditionally, these careers professionals have concentrated on providing career information, advice and guidance, but more recent developments have focused on the role of providing career education (see, for example, OECD, 2004, Career Services, 2009, and Ministry of Education, 2009,). Given the issues raised in the above citations from Buchanan (2006), Quintini (2011) and OECD (2011), it has been argued that these professionals need to be strongly involved in networking activities, as discussed in the next section.

\section{Networking Activities and Careers Education}

Modern information and communications technology means that young people are able to access any amount of information about career opportunities and education options that they choose. This raises a crucial question for people acting in careers roles in educational organisations, as summarised by Vaughan and O'Neil (2010, p. 8):

... as Shirkey [2008] has shown in his work on the demise of professions based on scarcity models, traditionally the work of careers advisors tended to be organised around things that were scarce - labour market information, tertiary institution information and vocational testing - but these things are now readily available through public information websites, marketing material and online self-testing resources. If people have access to what was previously scarce and in the sole domain of the careers advisor, and schools take seriously the Ministry of Education's suggestion that "all teachers are career teachers" now, what should the designated careers advisor be doing?

Vaughan and O'Neil responded to that question with an exploration of the networks and networking activities of careers educators in schools. ${ }^{3}$ Although networking is well recognised as important for careers practitioners (Watts, 1994; Career Services, 2009, p. 43; Cedefop, 2009, Ministry of Education, 2009, p. 20), Vaughan and O'Neil's (2010) report was the first study internationally to specifically examine the practice of networking as a core task or competency of careers advisors. Their case studies found that careers educators in New Zealand secondary schools were organically involved in developing multiple and overlapping career education networks. These decentralised networks concentrated on local connections but some extended outside the school's region.

Vaughan and O'Neil strongly supported the development of these networks. They observed that "meeting the needs of young people today now involves establishing a far wider range of working relationships inside and outside of the school" (Vaughan and O'Neil, 2010, p. iii). The activity of networking "allows a community of practice to be built across schools, education sectors, and community organisations (including employers and industry) on a regional and national basis" (ibid). Hence they made some specific recommendations (ibid):

\footnotetext{
${ }^{3}$ Publicly-funded educational services in some countries are provided through local education authorities run by local councils. New Zealand's public primary and secondary school system is funded directly through central government, but school Boards of Trustees have a degree of autonomy subject to meeting National Administration Guidelines and other statutory requirements.
} 
We suggest that the selection and training of careers staff needs to take account of new network and community membership and to enhance individuals' capacity to engage in networking. We also suggest that networks and networking be recognised and valued as a professional activity. Networks can be further developed as communities of practice, perhaps with the assistance of a "professional spine" to give cohesion to what is a diffuse set of ideas, activities, and actors in a very dynamic environment.

The Vaughan and O'Neil (2010) study also resonates with current research on the potentially important role of networks in promoting regional economic development, which has been summarised in a recent special issue of Regional Studies introduced by Rutten and Boekema (2012). These authors take as their historical starting point the idea of a 'knowledge economy', which initially led to suggestions that regional knowledge-based networks are loci for regional learning and innovation that strengthens regional competitiveness. Those suggestions are now thought to be too restrictive: "though learning may have a regional dimension, it is increasingly unrealistic to conceptualize learning as a regional phenomenon, because knowledge is distributed globally and innovative regions (and networks) are globally linked" (Rutten and Boekema, 2012, p. 986).

Despite the importance of national and global linkages, learning networks may be regionally embedded, because proximity appears to make a difference to learning opportunities (including fostering social contexts that may or may not be supportive of openness, tolerance and socio-cultural diversity, although regions harbour multiple social contexts; idem, p. 988). Rutten and Boekema (2012, p. 989) observe:

Various social contexts, such as social and professional networks, are relevant for learning and learning benefits from individuals bridging multiple networks (Amin and Roberts, 2008). As these networks may be embedded in firms, networks and places, their characteristics are relevant to explain learning.

Thus Vaughan and O'Neil's study and the international literature on regional development both point to networks that are multiple, overlapping, regionally embedded and extending beyond the local region. These insights provide important lessons for thinking about practical ways to support professional networks for careers professionals working in a local or regional context.

The networking concept is similarly relevant for careers education in tertiary education organisations. This possibility was explored in a case study by the author involving the Careers, Internships and Employment (CI\&E) centre of the University of Canterbury in Christchurch, New Zealand. CI\&E is a dedicated service with four professional staff, including a manager and two career consultants who are experienced and qualified members of the Career Development Association of New Zealand (CDANZ).

The research method adopted for studying the role of CI\&E was the soft systems approach developed at Lancaster University in the United Kingdom (see Checkland and Poulter, 2006, and the references in that book). The approach begins by defining the situation that the researcher wants to explore. The situation in this study was how a careers centre in a tertiary 
education institution carries out its mission to assist students, graduates, employers and the university's academic staff in career decision making and job searching.

In thinking about this situation, the soft systems methodology stresses that all people involved in the system should be presumed to be acting purposefully. Soft systems methodology seeks to understand this purposeful action and the way in which it creates systems that can be understood using relevant models. Consequently, the research partners prepared summaries of the presumed purposeful activities of employers, students and faculties, using the soft systems 'PQR' approach which adopts the following pattern: A stakeholder group does $P$ by carrying out $Q$ in order to contribute to $R$. Thus $P, Q$ and $R$ answer the questions: what does it do; how does it do it; and why does it do it? The three 'PQR' statements agreed by the research team were as follows.

Employers recruit the best people with the right skills to fill particular vacancies, by profiling the opportunities and rewards they offer and by interviewing a number of screened applicants, in order to contribute to their enterprise's commercial and other goals. Faculties produce successful graduates with efficient use of academic time, by providing students with well-designed learning opportunities and by awarding qualifications that are respected by stakeholders, in order to make their programmes more attractive to potential students. Students discover, discipline and display their capabilities and skills, by engaging in structured and unstructured learning activities and by building up a CV of formal qualifications and other achievements, in order to grow as a person and widen their range of possible life choices.

Consistent with the soft systems methodology, the interaction of these purposeful agents creates a system that CI\&E can facilitate. Thus CI\&E is team that also acts purposefully; hence it was possible to formulate a summary of their work using the same PQR formula as follows: CI\&E proactively engages and works with students, faculties and employers achieving their career and employment-oriented goals, by using its professional and financial resources to design and deliver an integrated set of services that adds value to these three groups, in order to contribute to the overall mission of the University of Canterbury. This statement recognised that the networks of the careers educators among students, faculties and employers were an important asset, allowing CI\&E to offer an integrated set of menus of services to these three groups of people.

\section{Proposal for a New Zealand System of Regional Skill Ecosystems}

The previous two sections have argued that regional networks are important for helping young people make good education employment linkages and for helping to reduce skill shortages reported by employers. New Zealand has a Crown entity responsible at the national level for "providing leadership and expertise across the careers sector, raising the quality of careers provision, developing careers resources, and providing services directly to the public to help them make smart decisions about work, education and training" (Careers New Zealand, 2011a, p. 2). Careers New Zealand has a high reputation as a reliable source of career information, advice and guidance (see the external review by Watts, 2007) and so provides a strong national spine for the country's system of careers education. 
The results of this study suggests that this national spine needs to be supplemented with regional ribs to be as effective as possible. Careers New Zealand already recognises the importance of regional networks; its Statement of Intent in 2012, for example, identified the need for "developing, implementing, co-ordinating and leading nationally and regionally based career networks and regional career strategies to improve the relevance, accessibility and ease of use of the career system to New Zealanders" (Careers New Zealand, 2012a, p. 9). The further insight from this study is to treat regional skill development systems as ecosystems, with careers offices in New Zealand secondary and tertiary education organisations (or the tutor or tutors performing that role in a small private training establishment) regarded as key actors for three reasons:

i. They are professional people in their field with existing networks of support and familiar with the Careers New Zealand resources;

ii. They are already engaged with students and employers in their normal day-to-day activities of service provision; and

iii. They are able to engage with educators within their organisation to help educators deliver good outcomes to their students.

Consistent with this approach, Careers New Zealand has developed Career Education Benchmarks for secondary schools and for tertiary education organisations. ${ }^{4}$ These benchmarks provide a self-review tool for tertiary organisations to assess the quality of their career development programmes and services, but they also provide information to students about the quality they should be able to expect from their provider's programmes and services. Both sets of benchmarks place students at the centre of the organisation's career development programmes, expressed in the following statement (Careers New Zealand, 2011b, p. 3, and 2012b, p. 4):

Central to the design of the benchmarks is the concept of supporting all students to build their own career management competencies so that they can successfully self-manage their life, learning and work. The benchmarks support the shift from a career decision guidance approach to a more dynamic model of career development guidance which reflects the realities of life, learning and work today.

The tertiary benchmarks identify three dimensions that work together to ensure these student competencies are achieved:

- Employer and Industry Engagement;

- Student Engagement; and

- Organisation Engagement.

\footnotetext{
${ }^{4}$ See http://www2.careers.govt.nz/educators-practitioners/planning/career-education-benchmarks/ for an overview and links to the benchmarks themselves. Two members of the Education Employment Linkages research team had some role in the preparation of the secondary and the tertiary level benchmarks. These benchmarks are designed to guide a voluntary self-review; a weakness, therefore, is that there is no provision for evaluation of their effectiveness in practice.
} 
These three dimensions involve the same set of actors (students, employers and faculties) highlighted in the study of the University of Canterbury CI\&E centre. These benchmarks, in the author's view, represent a welcome invitation for people offering careers services in tertiary education organisations to exercise leadership as key nodes in their regional skill ecosystem.

\section{Conclusion}

The OECD $(2012$, p. 3) describes skills as "the global currency of the 21st century". Young people at secondary school every week make education choices that over time are crafting who they are, are crafting who they can become, and are crafting where they can go. These choices include choices about what subjects to study, about how hard to study, about how to study both inside and outside the classroom, about how to integrate their study and their life experiences, and about how to display their mastery of the subjects studied. All of these choices made week after week and month after month will develop skills (or not) that will provide the global currency to open doors (or not) to different life pathways.

Skills in the local labour force are also critical for a region's economic development. Skill gaps can act as a constraint on the growth of enterprises or the attraction of new employers. As Finegold (1999) first recognised, some industries in some regions have evolved to sustain mutually reinforcing growth in supply of and demand for the high skills needed to generate major research breakthroughs, new forms of business services and flexible, high-technology start-ups.

This paper has considered the coordination problem in skills formation and utilisation from the perspective of the young person making investment decisions in their education (section 1) and from the perspective of employers motivated by profits through matching market opportunities with investment in capital matched with productive employees utilising that capital to take advantage of the market opportunities (section 2). This produced the model of a regional skill ecosystem in Figure 3.

The remainder of the paper has used that skill ecosystem model to propose that regional skill development systems be treated as ecosystems, with careers offices in New Zealand secondary and tertiary education organisations regarded as key actors in those ecosystems. This proposal was derived from the literature on networking activities for career professionals in secondary schools and in tertiary education organisations (section 3). Section 4 finished by noting the important step taken in this direction in New Zealand by the recent development of Career Education Benchmarks for secondary schools and for tertiary education organisations.

The recent OECD strategic approach to skills policies begins its report with the following warning: "Without adequate investment in skills, people languish on the margins of society, technological progress does not translate into economic growth, and countries can no longer compete in an increasingly knowledge-based global society" (OECD, 2012, p. 10). It is no exaggeration to say that helping its young people learn how to make great education choices is one of the most important investments that can be made in a region's future. 


\section{References}

Amin, A. and J. Roberts (2008) Knowing in action: Beyond communities of practice. Research Policy, 37(2), pp. 353-369.

Arcidiacono, P. (2004) Ability sorting and the returns to college major. Journal of Econometrics, 121(1-2), pp. 343-375.

Altonji, J. G. (1993) The demand for and return to education when education outcomes are uncertain. Journal of Labor Economics, 11(1), pp. 48-83.

Becker, G. (1962) Investment in human capital: A theoretical analysis. Journal of Political Economy, 70(5, Part 2), pp. 9-49.

Becker, G. (1964) Human Capital: A Theoretical and Empirical Analysis, with Special Reference to Education. New York: Columbia University Press.

Boven, R., C. Harland and L. Grace (2011) More Ladders, Fewer Snakes: Two Proposals to Reduce Youth Disadvantage. Discussion paper 2011/1. Auckland: New Zealand Institute.

Buchanan, J. (2006) From 'Skill Shortages' to Decent Work: The Role of Better Skill Ecosystems. Sydney: NSW Board of Vocational Education and Training.

Buchanan, J., D. Finegold, K. Mayhew and C. Warhurst, Eds. (forthcoming) The Oxford Handbook of Skills and Training. Oxford: Oxford University Press.

Buchanan, J. and M. Jakubauskas (2010) The political economy of work and skill in Australia: Insights from recent applied research. Chapter 3 in J. Bryson (Ed) Beyond Skill: Institutions, Organisations and Human Capability. London: Palgrave Macmillan, pp. 3257.

Buchanan, J., K. Schofield, C. Briggs, G. Considine, P. Hager, G. Hawke, J. Kitay, G. Meagher, J. Macintyre, A. Mounier and S. Ryan (2001) Beyond Flexibility: Skills and Work in the Future. Sydney: NSW Board of Vocational Education and Training.

Career Services (2009) Career Education in Practice. Wellington: Career Services.

Careers New Zealand (2011a) Briefing for the Incoming Minister. Wellington: Careers New Zealand.

Careers New Zealand (2011b) Career Education Benchmarks: A Set of Quality Benchmarks for Career Development Services in New Zealand Secondary Schools. Wellington: Careers New Zealand, available at www.careers.govt.nz.

Careers New Zealand (2012a) Statement of Intent for the Years 2012/13-2014/15. Wellington: Careers New Zealand.

Careers New Zealand (2012b) Career Education Benchmarks - Tertiary: A Self-Review Tool for Career Development Programmes and Services in New Zealand Tertiary Organisations. Wellington: Careers New Zealand, available at www.careers.govt.nz.

CDC (2010) Christchurch Economic Development Strategy. Christchurch: Canterbury Development Corporation. 
Cedefop (2009) Professionalising Career Guidance: Practitioner Competences and Qualification Routes in Europe. Cedefop Panorama series 164. Luxembourg: European Centre for the Development of Vocational Training.

Checkland, P. and J. Poulter (2006) Learning for Action: A Short Definitive Account of Soft Systems Methodology and its Use for Practitioners, Teachers and Students. Chichester: John Wiley.

Committee for Auckland (2012) Fuelling our Economy: Auckland Workforce Skills from the Employers' Perspective. Auckland: Committee for Auckland.

Crespo Cuaresma, J., G. Doppelhofer and M. Feldkircher (2014) The determinants of economic growth in European regions. Regional Studies, 48(2), pp. 44-67.

Dalziel, P. (2010) Developing the next generation: Employer-led channels for education employment linkages. Chapter 8 in J. Bryson (Ed) Beyond Skill: Institutions, Organisations and Human Capability. London: Palgrave Macmillan, pp. 154-175.

Dalziel, P. (2011a) "Regional Skills Ecosystems: The Role of Career Educators in the Region's Education Institutions." Paper presented to the Pacific Regional Science Conference (PRSCO), Seoul, 3-6 July.

Dalziel, P. (2011b) "Recreating Full Employment." The 2011 Bruce Jesson Memorial Lecture, Maidment Theatre, University of Auckland, 26 October, published at www.brucejesson.com/lectures.

Dalziel, P. (2012) Towards a New Zealand System of Skill Ecosystems. EEL Research Report No. 11. Lincoln University: AERU, available at www.eel.org.nz.

Eckstein, Z. and K. I. Wolpin (1999) Why youths drop out of high school: The impact of preferences, opportunities, and abilities. Econometrica, 67(6), pp. 1295-1339.

Finegold, D. (1999) Creating self-sustaining, high-skill ecosystems. Oxford Review of Economic Policy, 15(1), pp. 60-81.

Glaeser, E. L., G. A. M. Ponzetto and K. Tobio (2014) Cities, skills and regional change. Regional Studies, 48(2), pp. 7-43.

Gluckman, P. (2011) Improving the Transition: Reducing Social and Psychological Morbidity During Adolescence. A Report from the Prime Minister's Chief Science Advisor. Auckland: Office of the Prime Minister's Science Advisory Committee.

Harmon, C., H. Oosterbeek and I. Walker (2003) The returns to education: Microeconomics. Journal of Economic Surveys, 17(2), pp. 115-155.

Heckman, J. J. and B. E. Honoré (1990) The empirical content of the Roy model. Econometrica, 58(5), pp. 1121-1149.

Keane, M. P. and K. I. Wolpin (1997) The career decisions of young men. Journal of Political Economy, 105(3), pp. 473-522.

Keane, M. P. and K. I. Wolpin (2000) Eliminating racial differences in schooling attainment and labor market success. Journal of Labor Economics, 18(4), pp. 614-652 
Mincer, J. (1958) Investment in human capital and personal income distribution. Journal of Political Economy, 66(4), pp. 281-302.

Ministry of Education (2009) Career Education and Guidance in New Zealand Schools. Wellington: Learning Media.

Miranda, G., P. Dalziel, C. Estolano, K. Krasnowski and G. Larcombe (2011) Climate Change, Employment and Local Development, Sydney, Australia. OECD Local Economic and Employment Development (LEED) Working Papers, 2011/14. Paris: OECD Publishing, available at http://dx.doi.org/10.1787/5kg20639kgkj-en.

OECD (2004) Career Guidance and Public Policy: Bridging the Gap. Paris: Organisation for Economic Co-operation and Development.

OECD (2008) Jobs for Youth: New Zealand. Country report prepared by Glenda Quintini. Paris: Organisation for Economic Cooperation and Development.

OECD (2011) Towards an OECD Skills Strategy. Paris: Organisation for Economic Cooperation and Development.

OECD (2012) Better Skills, Better Jobs, Better Lives: A Strategic Approach to Skills Policies. Paris: OECD Publishing, http://dx.doi.org/10.1787/9789264177338-en.

Quintini, G. (2011) Right for the Job: Over-Qualified or Under-Skilled? OECD Social, Employment and Migration Working Papers, No. 120. Paris: OECD Publishing, available at http://dx.doi.org/10.1787/5kg59fcz3tkd-en.

Riley, J. (2001) Silver signals: Twenty-five years of screening and signalling. Journal of Economic Literature, 34(2), pp. 432-478.

Rousseau, J.-J. (1762) Émile. Translated and annotated by A. Bloom. London: Penguin, 1991.

Roy, A. (1951) Some thoughts on the distribution of earnings. Oxford Economic Papers, 3(2), pp. 135-146.

Rutten, R. and F. Boekema (2012) From learning region to learning in a socio-spatial context. Regional Studies, 46(8), pp. 981-992.

Shirkey, C. (2008) Here Comes Everybody. The Power of Organising Without Organisations. London: Penguin.

Shultz, T. W. (1961) Investment in human capital. American Economic Review, 51(1), pp. 1-17.

Sianesi, B. and J. Van Reenen (2003) The returns to education: Macroeconomics. Journal of Economic Surveys, 17(2), pp. 157-200.

Spence, M. (1973) Job market signalling. Quarterly Journal of Economics, 87(3), pp. 355-374.

Tobias, J. L. and M. Li (2004) Returns to schooling and Bayesian model averaging: A union of two literatures. Journal of Economic Surveys, 18(2), pp. 153-180.

Vaughan, K. and P. O'Neil (2010) Career Education Networks and Communities of Practice: A Report from the School-Communities Strand of the Education Employment Linkages Project. EEL Research Report No. 6. Lincoln University: AERU, available at www.eel.org.nz. 
Watts, A. G. (1994) The occupational profiles of vocational counselors in Europe. Journal of Counseling \& Development, 73(1), pp. 44-50.

Watts, A. G. (2007) Career Services: A Review in International Perspective. Wellington: Careers New Zealand.

Weiler, W. C. (1994) Expectations, undergraduate debt and the decision to attend graduate school: A simultaneous model of student choice. Economics of Education Review, 13(1), pp. 29-41.

Weiss, A. (1995) Human capital vs. signalling explanations of wages. Journal of Economic Perspectives, 9(4), pp. 133-154.

Windsor, K. and C. Alcorso (2008) Skills in Context: A Guide to the Skill Ecosystem Approach to Workforce Development. Sydney: NSW Department of Education and Training. 